\title{
Twenty-year assessment of four tree species planted in the mountain hemlock zone of coastal British Columbia ${ }^{1}$
}

\author{
by D. Burgess ${ }^{2}$, A.K. Mitchell ${ }^{2}$ and G. Goodmanson ${ }^{2}$
}

Concerns about low seedling survival and poor growth in plantations in montane areas resulted in a study to assess the field performance of amabilis fir (Abies amabilis (Dougl. Ex Loud) Dougl. Ex J. Forbes), noble fir (Abies procera Rehd.), yellow cedar (Chamaecyparis nootkatensis (D. Don) Spach) and mountain hemlock (Tsuga mertensiana (Bong.) Carrière). Seedlings were planted on six sites within the Mountain Hemlock zone of coastal British Columbia. The most recent results, based on a field assessment completed 20 years after the study was started, are presented. Little variation was noted among seedling stock types or between fall and spring planting. Seedling survival was greater than $78 \%$ for all four species. Although the sites were initially considered similar, large differences in productivity and species response on the six sites are now evident.

Key words: silviculture, high-elevation forestry, montane forests, reforestation, seedling establishment, Abies amabilis, Abies procera, Chamaecyparis nootkatensis, Tsuga mertensiana

Les inquiétudes relevées suite au faible taux de survie et à la faible croissance des plantations dans les régions montagneuses ont entraîné une étude d'évaluation de la performance au champ du sapin gracile (Abies amabilis (Dougl. Ex Loud) Dougl. Ex J. Forbes), du sapin noble (Abies procera Rehd.), du cèdre jaune (Chamaecyparis nootkatensis (D. Don) Spach) et de la pruche de montagne (Tsuga mertensiana (Bong.) Carrière). Les semis ont été plantés dans six sites inclus dans la zone de la pruche de montagne sur la côte de la Colombie-Britannique. Les plus récents résultats, établis à partir de l'évaluation complétée 20 ans après le début de l'étude, sont présentés. Peu de variation a été dénotée parmi les types de semis ou entre les plantations d'automne et de printemps. La survie des semis a été supérieure à $78 \%$ pour les quatre espèces. Même si les sites étaient considérés comme étant similaires, de grandes différences au niveau de la productivité et de la réponse des espèces sur les six sites sont maintenant évidentes.

Mots clés : sylviculture, foresterie de haute altitude, forêts de montagne, reboisement, établissement des semis, Abies amabilis, Abies procera, Chamaecyparis nootkatensis, Tsuga mertensiana

\section{Introduction}

Forest companies are harvesting more timber from higher elevations in montane and subalpine forests to meet their timber supply needs. This trend began in coastal British Columbia (BC) as the supply of easily accessible timber declined at lower elevations. These forests are found between $600 \mathrm{~m}$ and $1200 \mathrm{~m}$ in elevation within the Coastal Western Hemlock (CWH) and Mountain Hemlock

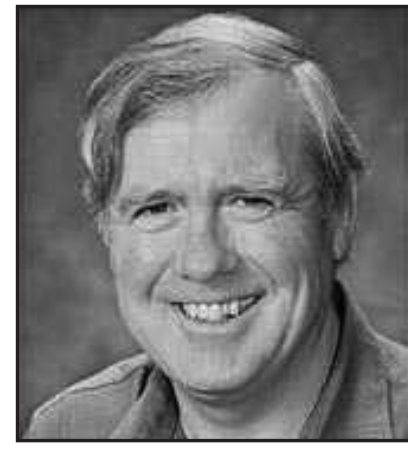

D. Burgess
$(\mathrm{MH})$ biogeoclimatic zones on Vancouver Island and the adjacent mainland coast (Klinka et al. 1984). The MH zone occurs above $950 \mathrm{~m}$ in elevation and comprises about 3.5 million ha (Erickson 2002).

Up to the early 1970s, Douglas-fir was the main species planted on the BC coast, even at higher elevations following clearcut logging and slashburning. Many early attempts at reforestation were not successful and a task force was set up by the Coastal Reforestation Board of British Columbia to evaluate the situation (Reuter 1973). Some of the Board's recommen-

$\overline{\text { 1Paper presented at "Mountain Forests: Conservation and Management," IUFRO }}$ Silviculture Conference, Vernon, British Columbia, Canada, July 28-August $1,2002$.

${ }^{2}$ Natural Resources Canada, Canadian Forest Service, 506 West Burnside Road, Victoria, British Columbia V8Z 1M5.

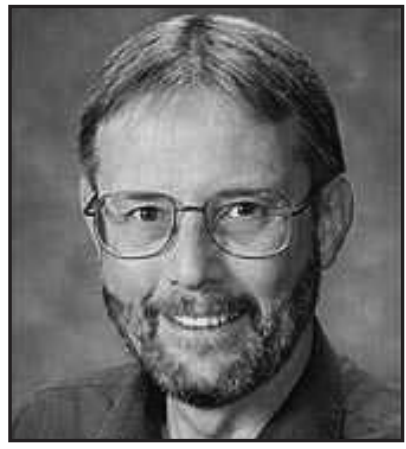

A. K. Mitchell

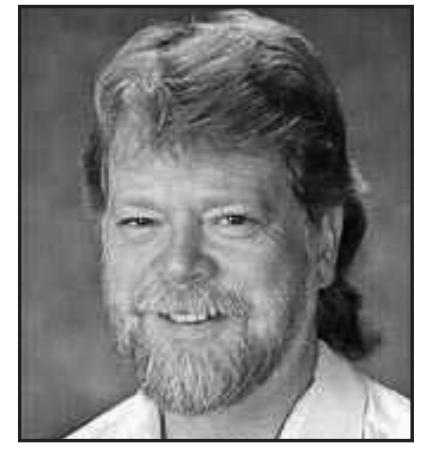

G. Goodmanson dations led to testing of alternative species and stock types at higher-elevation sites.

The need for tree species selection on a site-specific basis to regenerate forests is recognized throughout BC (Klinka and Feller 1984, Klinka et al. 1984, Anon. 1994). This involves assessing species for reliability, productivity and feasibility considering the level of survival, rate of growth, stem form and quality, and management costs. Early results indicated that high-elevation species performed better than lower-elevation species on high-elevation sites (Scagel et al. 1989). The experiment described here was one of the first of its kind set up in coastal $\mathrm{BC}$ to compare the performance of four tree species planted on six sites in the MH biogeoclimatic zone. This paper presents results on tree survival, growth and injuries from a 20-year assessment. 
Table 1. Planting trial locations and site information.

\begin{tabular}{|c|c|c|c|c|c|c|}
\hline Study site & Lat. & Long. & Elev. (m) & $\begin{array}{l}\text { Soil moist. } \\
\text { regime }^{\mathrm{a}}\end{array}$ & $\begin{array}{c}\text { Soil nutrient } \\
\text { regime }\end{array}$ & History $^{b}$ \\
\hline $\begin{array}{l}\text { Mt. Arrowsmith } \\
\text { (AR) }\end{array}$ & $49^{\circ} 14^{\prime} 50^{\prime \prime}$ & $124^{\circ} 36^{\prime} 40^{\prime \prime}$ & 1075 & Fresh & Med. & L76 \\
\hline $\begin{array}{l}\text { Mt. Cain } \\
\text { (CA) }\end{array}$ & $50^{\circ} 12^{\prime} 30^{\prime \prime}$ & $126^{\circ} 20^{\prime} 00^{\prime \prime}$ & 1100 & Fresh & $\begin{array}{l}\text { Poor- } \\
\text { Med. }\end{array}$ & $\begin{array}{l}\text { L66 } \\
\text { B67 }\end{array}$ \\
\hline $\begin{array}{l}\text { GuyLine Rd. } \\
\text { (G1\&G2) }\end{array}$ & $49^{\circ} 22^{\prime} 00^{\prime \prime}$ & $122^{\circ} 02^{\prime} 00^{\prime \prime}$ & 1050 & Fresh & $\begin{array}{l}\text { Poor- } \\
\text { Med. }\end{array}$ & $\begin{array}{l}\text { L74 } \\
\text { B75 }\end{array}$ \\
\hline $\begin{array}{l}\text { IronRiver } \\
\text { (IR) }\end{array}$ & $49^{\circ} 49^{\prime} 30^{\prime \prime}$ & $125^{\circ} 28^{\prime} 00^{\prime \prime}$ & 1070 & Fresh & $\begin{array}{l}\text { Poor- } \\
\text { Med. }\end{array}$ & L73 \\
\hline $\begin{array}{l}\text { Meade Creek } \\
\text { (ME) }\end{array}$ & $48^{\circ} 54^{\prime} 20^{\prime \prime}$ & $124^{\circ} 09^{\prime} 30^{\prime \prime}$ & 1000 & Moist & $\begin{array}{l}\text { Med. - } \\
\text { Rich }\end{array}$ & L77 \\
\hline
\end{tabular}

${ }^{a}$ Moisture / nutrient regime follows Green and Klinka (1994).

${ }^{b} \mathrm{~L}=\operatorname{logged}, \mathrm{B}=$ slashburned, numbers refer to year.

\section{Materials and Methods}

The field experiments were set up using a randomized block design with four replicates at each of six study sites (Table 1). All locations were within the windward moist variant ( $\mathrm{mm} 1)$ of the MH biogeoclimatic zone (Arnott et al. 1995). The four species planted at each study area were amabilis fir (Abies amabilis (Dougl. Ex Loud) Dougl. Ex J. Forbes), noble fir (Abies procera Rehd.), yellow cedar (Chamaecyparis nootkatensis (D. Don) Spach), and mountain hemlock (Tsuga mertensiana (Bong.) Carrière). In the $\mathrm{MH}$ zone, amabilis fir and mountain hemlock grow in association with lesser amounts of a number of other tree species including yellow cedar. Three stock types were tested: a container grown plug (PSB $2111+0$, i.e., seedlings grown for one year in the greenhouse in polystyrene (Styrofoam block) containers, each with a 2-cm top diameter and 11-cm depth), a container grown plug transplant (PSB 211 $1+1$, i.e., plug seedlings grown for one year in the greenhouse and then transplanted to an outdoor nursery for one year) and a field-grown seedling type (Bareroot 1+1, i.e., no container used, seedlings grown outdoors for one year in a seedbed and for one additional year in a transplant bed).

The study areas were planted in fall and spring during a twoyear period from fall 1978 to spring 1980. Seedlings were planted at a 2-m $\times 2-m$ spacing in row plots with 25 seedlings per row. With 25 seedlings per row, two planting seasons, four species, three stock types and four replicates, a total of 2400 seedlings were planted per site, if all treatment combinations were included. On three sites (Iron River, Mount Cain and Guyline Road 2), not all three stock types were available for noble fir because of poor seed germination. Seed was selected from available seedlots using the most appropriate seed zone for each site for amabilis fir, mountain hemlock and yellow cedar. As noble fir does not grow naturally in British Columbia, its seed was obtained from Washington, USA. Details about seed origin, seedling production methods and the results from earlier assessments, up to age 13 years of age after outplanting, were described elsewhere (Arnott and Pendl 1994).

A 20-year assessment of seedling survival, height and diameter growth, and injuries was completed in 1999 and 2000. All planted trees were tallied as either live or dead, and the most likely cause of death was noted. Total height was measured using various height poles or clinometers. Diameters at $30 \mathrm{~cm}$ above ground were measured with a diameter tape or cal- lipers. All planted trees were examined and injuries noted. Analyses were conducted as described earlier (Arnott and Pendl 1994) by fitting a split-plot ANOVA model with area, species, planting season and stock type as fixed effects, block as a random effect and using two subsets of data. The first subset included all six sites but was limited to three species (mountain hemlock, amabilis fir and yellow cedar) that were planted in all treatment combinations. The second subset included all four species but was limited to three sites (Guyline Road 1, Mt. Arrowsmith and Meade Creek) that were planted in the first planting year with all combinations of season and stock type for all four species. Three response variables were analyzed to determine statistical significance: survival (angular transformation of percent survival by row), total height, and diameter at age 20 .

\section{Results}

The survival of mountain hemlock and amabilis fir at age 20 was influenced by area $(p=.01)$. Seedling survival of all four species was little affected by planting season or stock type at year 20. The exceptions were for amabilis fir stock type $(\mathrm{p} \leq .01)$ at Iron River and Mount Cain, for noble fir stock type (fall planting only) at Meade Creek and at Guyline Road 1 $(\mathrm{p}=.01)$ and Guyline Road $2(\mathrm{p} \leq .01)$ and yellow cedar stock type at Iron River $(\mathrm{p}=.01)$ (fall planting only). Survival varied by area from $72.4 \%$ at Meade Creek to $95.4 \%$ at Guyline Road 2 for mountain hemlock. It ranged from $73.9 \%$ at Mt. Cain to $85.3 \%$ at Guyline Road 2 for amabilis fir, from $72.2 \%$ at Meade Creek to $85.1 \%$ at Guyline Road 1 for noble fir, and from $81.2 \%$ at Guyline Road 1 to $95.6 \%$ at Mount Cain for yellow cedar.

The major causes of seedling mortality were similar for all four species, but there were differences among species in the proportion and age of trees killed by the various causes. In the first three to five years, the major cause of mortality was poor microsite selection; either too dry or too wet. From five to eleven years after outplanting, depending on species, the major cause of seedling mortality was smothering of seedlings from tall competitive species, such as fireweed (Epilobium angustifolium). Root rot was the major cause of mortality thereafter, especially for mountain hemlock (Table 2).

Total height of all four species at age 20 was affected by site (Fig. 1a). The height of mountain hemlock varied with an interaction $(\mathrm{p}=.03)$ between area and stock type. The total height 
Table 2. Principal causes of mortality in high-elevation planted mountain hemlock (Hm), amabilis fir (Ba), noble fir (Bn), and yellow cedar (Cy), by assessment period

\begin{tabular}{|c|c|c|c|c|c|c|}
\hline Species & Year & Poor Microsite ${ }^{\text {a } \%)}$ & Smothering $^{\mathrm{b}}(\%)$ & $\operatorname{Root} \operatorname{Rot}^{c}(\%)$ & Other $(\%)$ & $\begin{array}{l}\text { Number of newly } \\
\text { dead trees assessed }\end{array}$ \\
\hline \multirow[t]{9}{*}{$\mathrm{Hm}$} & 1 & $45.1^{d}$ & 7.9 & 0 & 47 & 51 \\
\hline & 2 & 65.8 & 5.7 & 0 & 28.5 & 35 \\
\hline & 3 & 58.3 & 0 & 0 & 41.7 & 12 \\
\hline & 5 & 22.2 & 59.3 & 3.7 & 14.8 & 27 \\
\hline & 7 & 18.2 & 36.4 & 18.2 & 27.2 & 33 \\
\hline & 9 & 12.5 & 29.2 & 54.2 & 4.1 & 48 \\
\hline & 11 & 11.2 & 5.6 & 74.1 & 9.1 & 54 \\
\hline & 13 & 2.6 & 1.3 & 92.5 & 3.6 & 79 \\
\hline & 20 & 0 & 1.7 & 97.8 & 0.5 & 232 \\
\hline \multirow[t]{9}{*}{$\mathrm{Ba}$} & 1 & 58.0 & 0.5 & 0 & 41.5 & 186 \\
\hline & 2 & 64.4 & 18.6 & 0 & 17 & 70 \\
\hline & 3 & 47.2 & 35.9 & 0 & 16.9 & 53 \\
\hline & 5 & 32.5 & 59.5 & 1.4 & 6.6 & 74 \\
\hline & 7 & 19.4 & 64.2 & 1.5 & 14.9 & 67 \\
\hline & 9 & 22.8 & 57.9 & 10.5 & 8.8 & 57 \\
\hline & 11 & 11.1 & 38.9 & 19.5 & 30.5 & 36 \\
\hline & 13 & 13.7 & 18.2 & 59.1 & 9 & 22 \\
\hline & 20 & 5.1 & 37.3 & 52.5 & 5.1 & 59 \\
\hline \multirow[t]{9}{*}{$\mathrm{Bn}$} & 1 & 53.3 & 0.5 & 0 & 46.2 & 199 \\
\hline & 2 & 74.1 & 9.3 & 0 & 16.6 & 54 \\
\hline & 3 & 70.0 & 10.0 & 0 & 20 & 20 \\
\hline & 5 & 40.6 & 37.5 & 6.3 & 15.6 & 32 \\
\hline & 7 & 24.4 & 36.5 & 19.5 & 19.6 & 41 \\
\hline & 9 & 17.6 & 32.4 & 38.2 & 11.8 & 34 \\
\hline & 11 & 26.9 & 23.1 & 38.5 & 11.5 & 26 \\
\hline & 13 & 5.3 & 26.3 & 57.9 & 10.5 & 19 \\
\hline & 20 & 3.5 & 17.5 & 71.9 & 7.1 & 57 \\
\hline \multirow[t]{9}{*}{ Cy } & 1 & 64.6 & 0.6 & 0 & 34.8 & 178 \\
\hline & 2 & 75.0 & 0 & 0 & 25 & 32 \\
\hline & 3 & 50.0 & 10.0 & 0 & 40 & 10 \\
\hline & 5 & 40.0 & 40.0 & 6.7 & 13.3 & 15 \\
\hline & 7 & 18.2 & 36.4 & 18.2 & 27.2 & 22 \\
\hline & 9 & 10.0 & 20.0 & 35.0 & 35 & 20 \\
\hline & 11 & 14.3 & 14.3 & 42.8 & 28.6 & 14 \\
\hline & 13 & 0 & 18.2 & 68.2 & 13.6 & 22 \\
\hline & 20 & 0 & 5.3 & 77.2 & 17.5 & 57 \\
\hline
\end{tabular}

${ }^{\mathrm{a}}$ Microsite is the combination of drought, submersion, erosion, and burying injuries.

${ }^{\mathrm{b}} \mathrm{S}$ mothering is competition from dense vegetation.

${ }^{\mathrm{c}}$ Root rot is any root pathogen but predominately Armillaria ostoyae (Romagnesi) Herink.

${ }^{\mathrm{d}}$ Bolded percent estimates indicate the major cause for that assessment period.

of amabilis fir and yellow cedar was affected by site $(\mathrm{p} \leq .01)$ and stock type $(\mathrm{p} \leq .01)$. Height of noble fir was influenced only by area $(\mathrm{p}=.02)$.

The diameters at age 20 of all four species varied with site (Fig. 1b). The diameters of mountain hemlock were affected by a three-way interaction among site, planting season and stock type. Diameters of amabilis fir differed by area $(p \leq .01)$ and stock type $(\mathrm{p} \leq .01)$. The diameters of yellow cedar were affected by an interaction between area and stock type $(\mathrm{p}=.04)$. Noble fir diameter was influence by interactions between both site and planting season $(\mathrm{p}=.02)$ and site and stock type $(\mathrm{p}=.03)$.

Considering the four tree species together, average tree height at age 20 ranged from $2.8 \mathrm{~m}$ at the least productive site (Mount Cain) to $5.2 \mathrm{~m}$ at the most productive site (Meade Creek). Mount Cain has a less productive soil (Table 1) and also it is $100 \mathrm{~m}$ higher in elevation and about $1.5^{\circ}$ in latitude further north than Meade Creek. The fastest-growing species at 20 years was noble fir, which reached an average height of $8.0 \mathrm{~m}$ and diam- eter (measured $30 \mathrm{~cm}$ above ground level) of $17.1 \mathrm{~cm}$ on the most productive site (Fig. 2a and 2b). Amabilis fir height growth appears to have improved during the last several years on the most productive site (Fig. 2a). The ranking of species was different on a lower productivity site with yellow cedar showing the best growth at age 20 (Fig. 2b).

\section{Discussion}

In most cases, seedling survival was high and a marked improvement from earlier reforestation efforts when Douglas-fir was the main tree species planted on these high-elevation sites (Reuter 1973). Seedling survival might have been slightly higher here, if tree planters had been able to select only the best planting microsites and had not been constrained by plot layout. Little variation was noted among seedling stock types or between fall and spring planting, although stock type did have some significant effects. Generally, the seedlings that were smaller when planted (i.e., seedlings of the PSB $2111+0$ stock type), have remained smaller. 

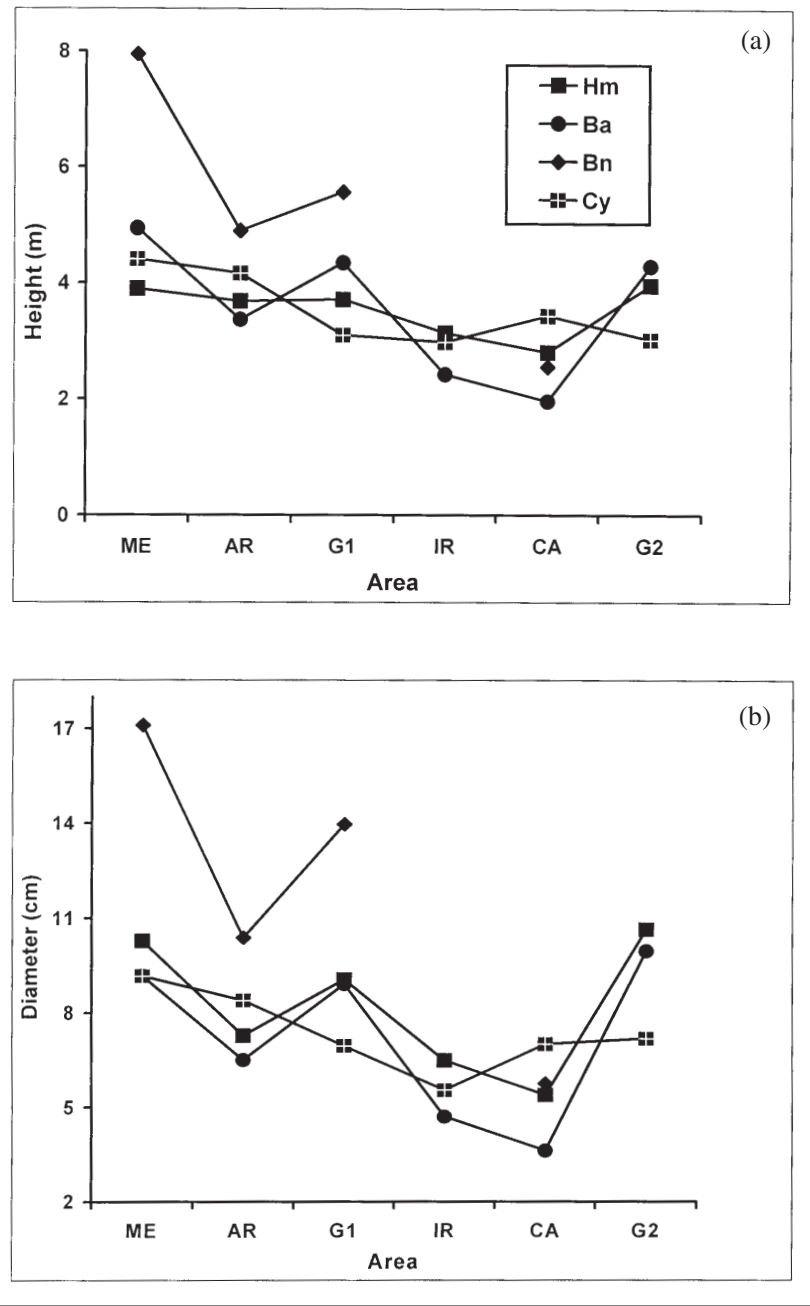

Fig. 1. (a) Mean tree height at age 20 of mountain hemlock (Hm), amabilis fir (Ba), noble fir (Bn), and yellow cedar (Cy) by area. (b) Mean tree diameter at age 20 (all species) by area.

The growth performance of an individual species varies widely with site conditions. At this stage of development, noble fir has grown very well on most sites and generally has straight single-stem form. While this species is not native, it appears to be well adapted to some high-elevation sites in BC. In most cases, its rapid early growth is better than that of the other species tested, and this suggests that it should receive further study and testing for use in coastal BC. However, noble fir did not perform well on all sites and yellow cedar appears able to outgrow it on some sites. Yellow cedar is highly valued, but it is particularly susceptible to breakage from heavy snows. The significance of this snow damage to future tree growth and wood quality remains to be determined.

The growth of amabilis fir has improved on some sites since the last measurement at age 13. While it is still too early to evaluate the significance of this improvement, it emphasizes the importance of monitoring these studies for long periods of time. Monitoring regeneration performance is a critical element in the development of knowledge about species and stock type suitability. The intensive evaluation of these study sites during the past 20 years has added new information on species
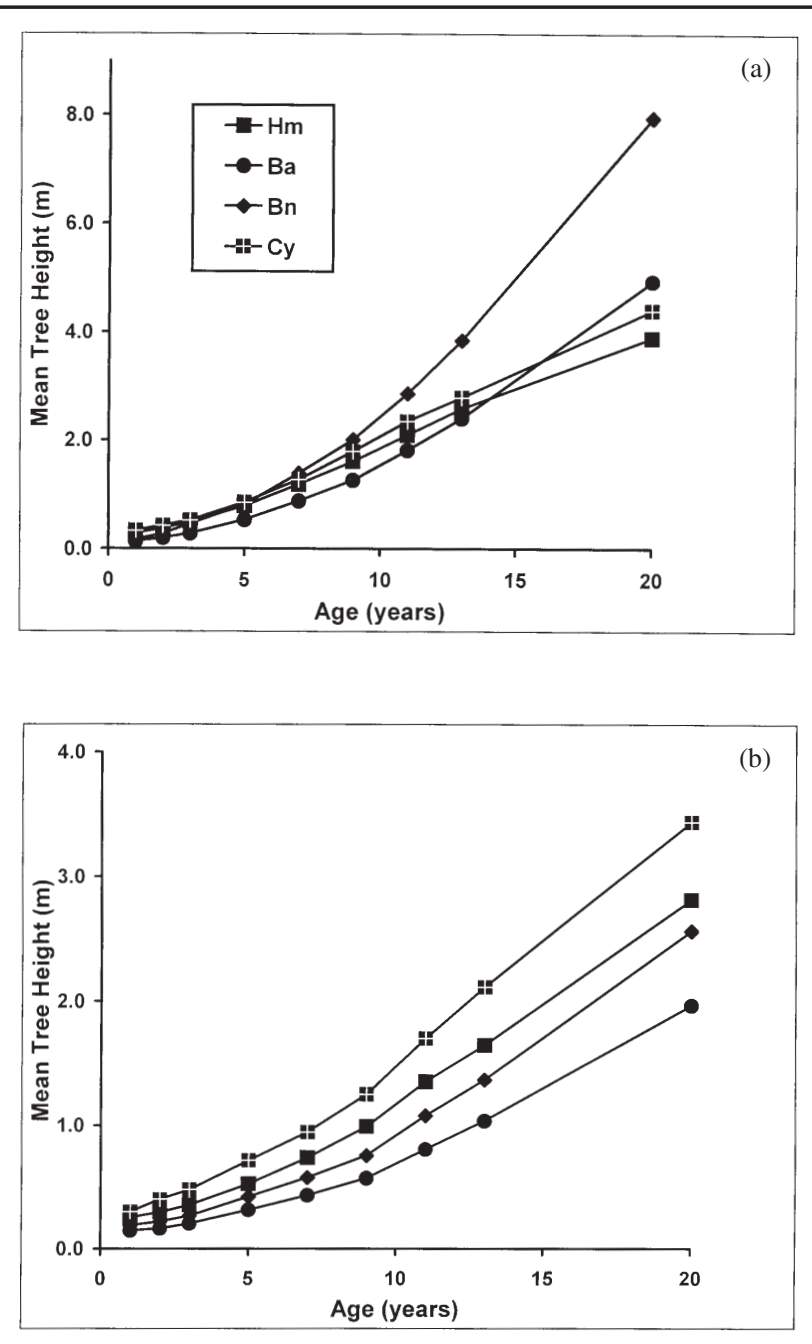

Fig. 2. (a) Tree height development at Meade Creek, a moist, medium-rich site: mountain hemlock (Hm), amabilis fir (Ba), noble fir (Bn), and yellow cedar ( $\mathrm{Cy}$ ) by age. (b) Tree height development at Mount Cain, a fresh, poor-medium site: mountain hemlock (Hm), amabilis fir $(\mathrm{Ba})$, noble fir $(\mathrm{Bn})$, and yellow cedar $(\mathrm{Cy})$ by age.

and stock type performance. Selecting the tree species, stand structure and reproduction method is a complex problem, which due to a lack of data and uncertainties about the future does not lend itself to easy answers and a definite choice of action (Klinka et al. 1994).

At high elevations, harvesting techniques and cutblock layouts that promote natural and preserve advance regeneration may be more appropriate than relying solely on planted seedlings (Scagel et al. 1989). This would involve a greater use of smaller cutblocks and a block orientation that protects regeneration from snow creep and high winds and acts as a seed source for natural regeneration. In such instances, it may be advisable to augment the natural regeneration by planting such high-valued species as yellow cedar.

\section{Conclusions}

Survival and growth of mountain hemlock, amabilis fir, noble fir and yellow cedar were generally acceptable 20 years after outplanting on high-elevation sites. As the study sites were all 
situated in the southern part of the MH zone, the results may not apply to more northerly areas.

Species performance varied among sites, but noble fir outperformed the other species tested in most cases, suggesting that its use could be increased. Yellow cedar can outperform the other species on some sites, but it is particularly susceptible to breakage from heavy snows. Future assessments are recommended to evaluate growth and wood quality and to confirm species selection guidelines.

\section{Acknowledgements}

We thank all the other people involved in either the establishment or assessments of this study. We especially wish to acknowledge Mr. J.T. Arnott (now retired from the Canadian Forest Service) and the late F.T. Pendl (formerly with the B.C. Ministry of Forests) who co-operatively designed and were responsible for setting up this study. Funding support from the BC Ministry of Forests, the Canadian Forest Service and the CanadaB.C. Partnership Agreement (FRDA II) is gratefully acknowledged.

\section{References}

Anon. 1994. Correlated guidelines for tree species selection and stocking standards for the ecosystems of British Columbia. $2^{\text {nd }}$ revised edition. FRDA II publication, Canada-British Columbia Partnership Agreement, Victoria, B.C. 328 p.

Arnott, J.T. and F.T. Pendl. 1994. Field performance of several tree species and stock types planted in montane forests of coastal British Columbia. Information Rep. BC-X-347. Natural Resources Canada, Canadian Forest Service, Pacific Forestry Centre, Victoria, B.C. 45 p.
Arnott, J.T., R.K. Scagel, R.C. Evans and F.T. Pendl. 1995. High elevation regeneration strategies for subalpine and montane forests of coastal British Columbia. FRDA Rep. 229. Canada-British Columbia Partnership Agreement on Forest Resource Development, Victoria, B.C. 30 p.

Erickson, B. 2002. Unpublished ARCVIEW summary from a British Columbia Ministry of Forests Biogeoclimatic Ecosystems Classification digital database accessed through the Internet, Pacific Forestry Centre, Victoria, BC.

Green, R.N. and K. Klinka. 1994. A field guide to site identification and interpretation for the Vancouver Forest Region. B.C. Min. For., Vancouver, B.C., Land Manage. Handbook No. 28.

Klinka, K., R.E. Carter and G.J. Kayahara. 1994. Forest reproduction methods for coastal British Columbia: principles, criteria, and a stand selection guide. For. Chron. 70: 569-577.

Klinka, K. and M.C. Feller. 1984. Principles used in selecting tree species for regeneration of sites in southwestern British Columbia. For. Chron. 60: 77-85.

Klinka, K., R.N. Green, P.J. Courtin and F.C. Nuszdorfer. 1984. Site diagnosis, tree species selection, and slashburning guidelines for the Vancouver Forest Region. B.C. Land Manage. Rep. 25, B.C. Min. For., Vancouver, B.C.

Reuter, F. 1973. High elevation reforestation problems in the Vancouver District: A Problem Analysis. B.C. Min. Forests, Research Division, Victoria, B.C. 46 p.

Scagel, R., B. Green, H. von Hahn and R. Evans. 1989. Exploratory high elevation regeneration trials in the Vancouver forest region: 10-year species performance of planted stock. FRDA Rep. 98, Canada / B.C. Economic and Regional Development Agreement, Victoria, B.C. 